\title{
Fundamental Problems of the Ethnography of Communication and Public Speech of the Albanian Language of Nowadays
}

\author{
Prof. Dr. Gjovalin Shkurtaj1 \\ Phd. Alessia Bergamin² \\ 1Albanian University, Tirana, Albania \\ 2University of Tirana, Faculty of Foreign Languages, Italian Language Department. \\ Email: shkurtajgj@gmail.com
}

\author{
Doi:10.5901/ajis.2015.v4n2s2p157
}

\section{Abstract}

The article tackles some fundamental problems of the ethnography of communication and public speech of nowadays Albanian, the directions and the main tendencies of contemporary developments and the influences from English and other foreign languages in the frame of globalization. Language has not been and it is not a monolith block: it has its layers and its distinctions in both the vertical line and the horizontal line as well. The vertical stratification (or diastratic) belongs to the variables that are connected with the social stratification, whereas the horizontal stratification (or diatopic) belongs to the dialectal and regional distinctions. These dimensions of linguistic variety are often interlaced with two additional ones: the degree of formality, which belongs to the manner and control that is exercised when spoken (diaphasic variation) and the variations that depend on the means used to communicate: written forms, by means of electronic post (e-mail), telephone, orally etc. (diamesic variation).

Keyword: Ethnography, public speech, disipline, theoretical linguistics.

The ethnography of public speech was born and is undergoing the process of development as a discipline that withstands this thematic by overthrowing some viewpoints of traditional theoretical linguistics, precisely due to the circumstances when it recovered and is stepping forward as a study of the language related to the society.

In this paper we will illustrate only some aspects connected with the fundamental problems of the ethnography of communication, as respect and the feminine gender, on the basis of equality of women to men. This phenomenon regards not only the name of professions and social/state jobs with equal condescension to women, but also the consequences that this phenomenon reflects on grammar.

Even if shortly, we find it interesting to treat this issue since it has begun to appear more and more frequently in scientific and education translations from foreign languages into Albanian. In the last years we have noticed that in the translations from German into Albanian that have been published it is systematically written schoolgirl /schoolboy, ${ }^{1}$ while in Albanian, as in other languages, prevails the words pupils/students/readers, which are used for males as for females. We make a couple of examples:

"The key to this process are adults - parents and teachers - who take part to the process of reading for the interest of schoolboys/schoolgirls, ${ }^{2}$ often quite different, with whom they can exchange their opinion on the contents of the books."

"Of course that schoolboys/schoolgirls ${ }^{3}$ can and must be requested to find online texts in original language and to use them."

In cases like these, as it is known, in Albanian, but also in many European languages, when we mention "pupil/pupils"4 it means that it is both for males and females. The same thing is when we mention "teacher/professor"s: in Albanian it is implied that both males and females are involved.

\footnotetext{
1 In Albanian nxënësja/nxënësi

2 In Albanian nxënësve/eve

3 In Albanian nxënësit/et

${ }^{4}$ In Albanian nxënës,-i a nxënës,-it

${ }^{5}$ In Albanian mësuesi/ profesori
} 
Perhaps this phenomenon, which is more clearly emphasized in official written German, may be considered fair because it takes into account the effects of the pressure from feminist movements and requirements of "equal opportunities" for women (in Italian pari opportunità). However, in terms of reading and studying such materials in which the name gender is always specified, the style may result dull.

This observation regarding new contemporary phenomena, that the US today Sociolinguistics calls it "Ethnography of Speech", needs to be examined more closely.

From a study of greetings and congratulations of Albanian language in comparison with Italian language, it turns out that the use of feminine gender in names related to professions has been studied by some of the most important Italian linguists such as Maurizio Dardano and Pietro Trifone. In their "Grammatica italiana con nozioni di linguistica", they point out that "social changes bring with them uncertainties and discussions in almost all areas; this can also be applied to the phenomena of the women emancipation, which has raised - among other things - some language doubts. As a matter of fact, ever since it disappeared the restrictions that prevented women from embarking on many careers, it has became necessary to create the feminine gender for many profession names that were once reserved only to men". (Dardano, 1995)

The authors emphasize that "there are some difficulties for new female professions, although there is a strong tendency to maintain the male form," as for example:

"il Ministro dell'agricoltura Giulia Rossi;

l'addetto stampa di Palazzo Grimaldi, signora Nadia Lacoste;

il giudice Margherita Gerunda."6

With reference to professions, the use of male names for both genders is also widespread in Albanian language too, even though other combinations are accepted, as for instance këngëtare femër, aktore femër, etc.. In Albanian, moreover, the difference between male and female names is stressed by precise suffixes as -e (këngëtar-këngëtare, aktor-aktore, punëtor-punëtore, rrobaqepës-rrobaqepëse); or -eshë (bari-bareshë, doktor- doktoreshë, bujk- bujkeshë).

In Italian it remains challenging cases such as il sindaco donna, il questore donna, il giudice donna, la donna soldato, la donna poliziotto, la donna magistrato ${ }^{7}$ where is clear the aim to avoid ambiguity. In Albanian there is a tendency to use, above all in media language, unnecessary loanwords that sound unnatural according to Albanian linguists instead of using the feminine suffix -e added to masculine names referred to professions (ministër-ministre, deputet-deputete, ushtar-ushtare, polic-police, oficer-oficere, ministër-ministre, kryeministër-kryeministre, ambasadorambasadore etc.), and even in the ranks of titles: doktor-doktore, profesor-profesore, or the typical consolidated Albanian formations through the suffix -eshë (profesoreshë, doktoreshë).

We would also analyze some phenomena related to the expressions of respect in Albanian, such as greetings and wishes, taking into consideration a broader study on this subject titled "Greetings and wishes in Albanian and Italian (compared sociolinguistic study)" (Bergamin, 2012) in which some important issues related to ethnography of speech have been analyzed. The study is based on a comparison between Italian and Albanian language, and it turned out that, despite the fact the two languages have many contact points with regard to greetings and wishes expressions, Albanian language has some peculiar linguistic aspects which Italian hasn't, as for example wishes expressions made while drinking coffee.

During our daily contacts with other people we use habitual verbal expressions that simplify communication and that, in some cases, become very important to maintain good relationships with others. Furthermore, it can be said that every language community uses as a means of communication expressions as: good morning ${ }^{8}$ or good afternoon ${ }^{9}$, good evening ${ }^{10}$, thank you ${ }^{11}$, goodbye ${ }^{12}$ (or in Italian: buongiorno ${ }^{13}$, buonasera, grazie, arrivedercilarrivederLa). So, in these cases, we notice that greetings expressions considerably differ from culture to culture. Often these structures or expressions may also change from one region to another in the same country.

\author{
6 Op. cit. above p. 195 \\ 7 Op. cit. above p. 195 \\ 8 In Albanian mirëmëngjesi \\ ${ }^{9}$ In Albanian mirdita \\ 10 In Albanian mirëmbrëma \\ 11 In Albanian faleminderit \\ 12 In Albanian mirupafshim \\ ${ }^{13}$ In Italian: buongiorno is used for saying both mirëmëngjesi/good morning and mirdita/good afternoon. There is no perfect equivalent to \\ mirëmëngjesi/good morning.
}


In Albanian, whether in the field of greetings or congratulations, curses etc., there are expressions of courtesy which are very different one from another, or even some expressions that cannot be translated with similar expressions. For instance in Albanian there is the greeting expression tungjatjeta ${ }^{14}$ (geg. tungatjeta, t'u ng-jatjeta, tyetjeta or simply tjeta; tosk. tungjatjeta, tunjatjeta, njatjeta), or in the abbreviated form tung, which is widely used in these last years above all in chats, and that does not exist in Italian and can only be paraphrased to understand its meaning. (Shkurtaj, 2001)

Another similar expression is te gjeturit, ${ }^{15}$ an expression used during meals. It is used in the South of Albania. Foreigners who visit southern Albania, even when they have a good knowledge of Albanian, they do not easily understand the meaning of such phrases: "E moj krushkë, si nuk më gjete një herë?" which it is not only difficult to translate, but also to understand, e.g. in Italian. When someone says të kam gjetur, the implied polite answer is: Ti që më gjete mua, të gjett e mira!

Even more difficult to understand for foreigners is the meaning of the wish expression turrem ${ }^{16}$ used in the provinces of the North of Albania: T'u turrsha implies the compelled answer Të pritsha e të paça! (Shkurtaj, 2001)

\section{References}

Arcuri N. (2000), Il saluto e i suoi rituali dall'antichità ad oggi, in Quaderni di Semantica, a. XXI, n. 1.

Bergamin A. (2012), "Mirësjellja gjuhësore dhe format e shprehjes së saj në shqipen e në italishten", PhD made under the supervison of prof. dr. Gjovalin Shkurtaj, Italian Department, University of Tirana.

Cortellazzo M. e Zolli P. (1979-88), DELI Dizionario etimologico della lingua italiana, 5 voll., Bologna.

Dardano M. e Trifone P. (1995), Grammatica Italiana con nozioni di linguistica, terza edizione, Zanichelli Editore, Bologna, p.195.

Goffman E. (1971b), Modelli di interazione, a cura di P.P. Giglioli, Il Mulino, Bologna.

Jespersen O. (1924), The Philosophy of Grammar, Allen \& Unwin, London.

Perini P. (1983), Struttura e uso di alcune formule di cortesia, in F. Orletti (a cura di), Comunicare nella vita quotidiana, II Mulino, Bologna.

Ronconi F. (2010), Grammatica essenziale della lingua italiana, Arnoldo Mondadori Editore, Milano, p.58.

Shkurtaj Gj. (2001), „Përshendetjet dhe urimet në gjuhën shqipe“, në Onomastikë dhe etnolinguistikë, Shblu, Tiranë.

\footnotetext{
14 It literally means "have a long life".

15 Used to drink a toast.

16 Used to drink a toast.
} 